\title{
MEMAHAMI KOMPLEKSITAS GROWTH TRIANGLES
}

\author{
Yusnarida Eka Nizmi ${ }^{1}$ \\ ${ }^{1}$ Program Studi Hubungan Internasional, Universitas Riau \\ email : eka_nizmi@yahoo.com
}

Korespondensi : eka_nizmi@yahoo.com

\begin{abstract}
This paper analyzes some of the main concepts in the scope of the growth triangle phenomenon which are divided into several discussions. It starts with the etymology of the growth triangle and discusses what distinguishes it from other forms of regional economic cooperation. The term Growth Triangles came after Singapore's deputy Pedana Minister Goh Chok Tong used it in December 1989 to describe subregional economic cooperation involving Singapore, South Johor and Batam Island in Indonesia. Growth Triangles, exploits complementarity among different countries geographically to get a competitive advantage in the context of export promotion. Growth Triangles display the characteristics of microlinkages, but are distinguished by the composition of tripartite. They are considered as "transnational economics" in which economies that have different resources from various factors of production, services, labor, capital, natural resources, existing efficiency, and the strengths of each country. In theory, the greater comaprative advantages that exist, it can guarantee the existing members to work together outside their national borders. Growth Triangle refers to the Comparative dimension. The peripheral economic areas, which are far from the main centers, particularly benefit. In the Growth Triangle we also find increased socio-economic incentives, namely opportunities to earn income and jobs.
\end{abstract}

Keywords: economic cooperation, prospects, growth, comparative advantage, complexity

\begin{abstract}
Abstrak
Tulisan ini menganalisa beberapa konseptual utama dalam lingkup fenomena growth triangle yang dibagi menjadi beberapa pembahasan. Diawali dengan etimologi dari growth triangle dan membahas apa yang membedakannya dengan bentuk kerjasama ekonomi regional lainnya. Terminologi Growth Triangles muncul setelah deputi Pedana Menteri Singapura Goh Chok Tong menggunakannya pada Desember 1989 untuk menjabarkan kerjasama ekonomi subregional yang melibatkan Singapura, Selatan Johor dan Pulau Batam di Indonesia. Growth Triangles, mengeksploitasi komplementaritas diantara negaranegara yang berbeda secara geografis untuk mendapatkan keuntungan kompetitif dalam rangka promosi ekspor. Growth Triangles menampilkan karakteristik-karakteristik mikrolinkages, namun dibedakan oleh komposisi tripartite. Mereka dianggap sebagai "transnational economic" dimana ekonomi-ekonomi yang memiliki perbedaan sumber daya dari ragam faktor produksi, jasa, tenaga kerja, modal, sumber daya alam, efesiensiefesiensi yang ada, dan kekuatan-kekuatan masing-masing negara. Dalam teori, lebih besar comaprative advantage yang ada, maka dapat menjamin anggota-anggota yang ada untuk bekerja secara bersama-sama diluar batas-batas negara mereka. Growth Triangle merujuk
\end{abstract}


pada dimensi Comparative tersebut. Area-area ekonomi pinggiran, yang jauh dari pusatpusat utama, secara khusus diuntungkan. Dalam Growth Triangle juga ditemukan insentif sosial-ekonomi yang meningkat yakni peluang-peluang mendapatkan pendapatan dan pekerjaan.

Kata kunci: kerjasama ekonomi, prospek, pertumbuhan, keuntungan kompetitif, kompleksitas

\section{PENDAHULUAN}

Satu dari perkembangan-perkembangan yang menarik dalam sistem perdagangan dunia pada tahun 1990an adalah kehadiran dan menguatnya blok-blok perdagangan regional. Sejumlah usulan yang ada di wilayah Asia Pasifik menunjukkan peningkatan kerjasama ekonomi dan liberalisasi perdagangan, namun dengan perolehan hasil yang masih terbatas. Beberapa kerjasama ekonomi yang terlokalisasi yang kemudian dikenal dengan sebutan growth triangles muncul di Asia. Salah satu ciri blok perdagangan ini, growth triangles mengeksploitasi komplementaritas diantara negara-negara yang berbeda secara geografis untuk mendapatkan keuntungan kompetitif dalam rangka promosi ekspor. Agar efektif, biasanya mereka mensyaratkan kerjasama antara sektor privat dan publik dari masing-masing negara yang terlibat. Secara umum, sektor privat menyediakan modal bagi investasi dan sektor publik memfasilitasi pertumbuhan infrastruktur, insentif fiskal, dan kerangka administratif.

Ketertarikan dalam growth triangles dipicu dengan suksesnya bagian selatan RRC dalam memperoleh angka pertumbuhan melalui kerjasama ekonomi dengan negara-negara tetangganya. Singapura mencoba untuk memformalkan kerjasama dengan negara bagian selatan Malaysia yakni Johor dan kepulauan Riau di Indonesia. Pembahasan-pembahasan untuk menciptakan growth triangles di bagian Asia yang lain mulai bermunculan termasuk Trumen River Area Development Program di Utara yang kian berkembang.

\section{PEMBAHASAN}

\section{Etimologi Growth Triangles.}

Growth Triangles yang juga dikenal dengan zona ekonomi subregional (Chia dan Lee, 1992), natural economic zones (Scalapino, 1992) atau extended metropolitan regions (McGee dan Macleod, 1996). Mereka adalah zona ekonomi transnasional yang menyebar, secara geografi terdiri dari tiga negara atau lebih yang memiliki perbedaan demi pencapaian promosi perdagangan dan investasi. Terminologi "growth triangle" muncul setelah Deputi Perdana Menteri Singapura, Goh Chok Tong, menggunakannya pada Desember 1989 untuk menjabarkan kerjasama ekonomi subregional yang melibatkan Singapura, Selatan Johor, dan Pulau Batam di Indonesia. Kerjasama ekonomi antara Hong Kong, Taipei dan selatan RRC (khususnya Propinsi Guangdong dan Fujian) yang kemudian dikencal sebagai Southern China Growth Triangle. Trumen River Area Development Program, yang melibatkan propinsi Jilin di RRC, Siberia di Russia, dan democratic People's Republic of Korea juga dianggap sebagai sebuah growth triangle. Growth 
triangle lain juga terbentuk yang melibatkan negara-negara utara ASEAN yakni Malaysia, wilayah Sumatra di Indonesia, dan Thailand bagian selatan. The Yellow Sea Economic Zones, yangmelibatkan Bohai di Cina dan bagian Barat dan Selatan dari Kyushu dan Yamaguchi di Jepang juga disebut dengan growth triangle.

Growth triangle merupakan hasil dari dua elemen yakni: kerjasama ekonomi regional dan arus investasi asing langsung yang besar (FDI). Pemikiran tradisional dari kerjasama ekonomi regional Asia adalah bahwa ini mampu mendorong ke arah peningkatan skala ekonomi, eksploitasi komplementaritas dalam hal produksi, dan memperluas pasar. Pemikiran ini diterima secara luas selama bertahun-tahun, hingga hampir semua kerjasama ekonomi regional yang diikuti oleh negara-negara yang mencoba mencari otonomi politik dan ekonomi setelah mereka lepas dari aturan kolonial. Ketertarikan dalam kerjasama regional, bagaimanapun terjadi dengan mengurangi ketegangan politik antar negara di wilayah tersebut, sebagai bagian dari proses produksi globalisasi, yang kemudian menggiring distribusi regional dari penciptaan integrasi vertikal yang terjadi. Negara-negara Asia merasa perlu untuk memahami sikap apa yang diperlukan dalam menanggapi fenomena tren proteksionis di negara-negara maju, European Community dan North American Free Trade Agreement (NAFTA) sebagi blok-blok perdagangan. Kerjasama regional saat ini dipandang sebagai sebuah media untuk meningkatkan pertumbuhan ekonomi.

FDI tumbuh dengan baik di Asia (seperti yang terlihat pada figure). Investasi awal di Asia terutama berorientasi pada pemanaatan sumber daya alam. Dimulai sekitar awal 1960an, arus investas lebih berorientasi pada ekspor barang-barang manufaktur. Keputusan-keputusan investasi didasarkan pada beragam faktor seperti ketersedian upah buruh yang murah dan kondisi serta kebijakan investasi yang mendukung operasional bisnis investasi. Pemain penting investasi yang berasal dari luar Asia perlahan mulai digantikan oleh pemain Asia seperti Jepang yang melakukan investasi di wilayah Asia Tenggara dan memicu pertumbuhan investasi yang luar biasa hingga membentuk negara-negara industri baru (Newly Industrializing Economics/NIEs).

Investasi untuk merelokasi manufaktur yang berbasis tenaga kerja murah meningkat tajam setelah terjadinya penurunan nilai mata uang yang diikuti dengan Plaza Accord 1980an. Investasi Jepang di ekonomi Asia muncul kembali pada tahun 1980an, ketika nilai Yen melonjak dan mengurangi biaya kompetisi dari para eksportir Jepang serta memaksa mereka untuk mencari basis produksi di luar Jepang.

Investasi di beberapa negara di Asia Tenggara dan beberapa bagian dari Cina menunjukkan pertumbuhan yang cukup fenomenal dalam tahun-tahun terakhir. Pertumbuhannya hampir mencapai 40 persen dalam dua tahun. Sejak 1987, lebih ari 4000 perusahaan menjalankan operasinya di Asia Tenggara, mengucurkan dana sekitar \$12 milyar ke wilayah tersebut. Meskipun sudah lama memiliki persoalan politik dan kekhawatiran dengan kebijakan dagang Amerika Serikat, 7000 perusahaan menjalankan operasional perusahaan di Cina, dengan total investasi mencapai \$6 milyar (International Economic Newsletter, March 1993).

Tingginya angka investasi ini iikuti dengan meningkatnya upah kerja. Oleh karena itu growth triangles menjadi sebuah solusi menarik bagi arus investasi yang berhadapan dengan tuntutan kenaikan upah. Dengan menghilangkan batasan-batasan 
masuknya arus investasi dan beragam input lainnya, melalui ragam kerjasama, secara geografis negara-negara yang berdekatan ini tetap dapat mempertahankan kompetisi ekspor mereka.

Masing-masing triangle memiliki kelompok investing countries dan receiving countries. Negara-negara kelompok investing countries biasanya memiliki supplai modal, teknologi, dan kemampuan manajemen terhadap investing countries. Hong Kong, Korea, Jepang, Singapura, dan Cina adalah para investor dalam growth triangles. Motif mereka untuk melakukan investasi dari persoalan upah sampai dengan strategi mendapatkan bahan mentah. Sebaliknya, anggota receiving countries memiliki tenaga kerja yang terampil dan tidak terampil, ketersediaan lahan, dan sumber daya alam lainnya. Kelompok receiving groups biasanya kelompok yang tingkat pertumbuhan ekonominya lebih rendah dibanding mereka yang masuk dalam kategori investing countries.

\section{Kebutuhan Akan Hadirnya Growth Triangles}

Negara-negara berkembang Asia, dimana ekonominya yang paling berkembang saat ini, mengambil langkah untuk menciptakan lingkungan ekonomi yang lebih liberal dan tebuka terhadap investasi. Hasilnya, meskipun perdagangan dunia menurun dan permintaan juga tidak terllau baik dalam dunia industri, negaranegara ini mampu mempertahankan tingkat pertumbuhan ekonomi dan performa ekspornya. Kesuksesan ini didukung oleh stabilnya arus investasi asing, yang membantu meningkatkan kapasitas produksi dan produktivitas tenaga kerja.

Negara-negara berkembang Asia, menjadi lebih terhubung dengan belahan dunia lainnya, menjadi lebih konsen terhadap kemunculan blok-blok perdagangan (seperti EC, dan NAFTA) terkait dengan ekspor dan arus modal. Tidak mengejutkan, kemudian beragam kelompok-kelompok ekonomi dan perdagangan Asia Pasifik diyakini dapat mempromosikan perdagangan.

Namun, bagaimanapun, ada masalah-masalah fundamental dalam pembentukan tipe EC atau NAFTA -blok perdagangan di Asia:

1. Blok-blok perdagangan mensyaratkan volume yang besar dari perdagangan internal. Meskipun perdagangan intraregional di Asia meningkat dalam tahun-tahun terakhir, Amerika Serikat dan EC masih menjadi pasar utama bagi ekspor Asia dan sumber-sumber impor. Pembagian perdagangan dengan EC dan Amerika Utara dalam total perdagangan Asia mencapai 40 persen pada tahun 1991.

2. Blok-blok perdagangan mensyaratkan negara-negara anggota memiliki aturan hukum dan regulasi pemerintah yang sama dalam hal perdagangan dan arus investasi. Negara-negara berkembang Asia, bagaimanapun memiliki keragaman dalam sistem ekonomi, yang menjadikannya sulit untuk menyeragamkan praktek-praktek perdagangan dan investasi.

3. Tingkat pendapatan perkapita negara-negara anggota harus tidak terlalu jauh berbeda sehingga penerapan ragam regulasi tidak akan menyebabkan perubahan-perubahan yang masif dalam mendistribusikan pendapatan dan pekerjaan (Schott, 1991). Disparitas pendapatan dari Jepang hampir 40 kali lipat dari Filipinan dan 100 kali lipat dari Vietnam. Perbedaan-perbedaan ini 
bahkan lebih besar dibandingkan diantara negara-negara EC dan Amerika Utara.

4. Kedekatan geografis seringkali menjadi elemen utama dari blok perdagangan dikarenakan pentingnya transportasi dan komunikasi. Namun, negara-negara berkembang Asia yang tersebar luas, dan transportasi merkea serta jaringan komunikasi justru seringkali kurang berkembang, sehingga membuat biaya transaksi menjadi tinggi.

5. Komitmen politik dan koordinasi kebijakan diantara negara-negara anggota adalah persyaratan yang fundamental bagi sebuah blok perdagangan. Namun lagi-lagi, negara-negara berkembang Asia memiliki kepentingan politik yang berbeda, latar belakang sejarah yang berbeda, dan sistem ekonomi sosial yang berbeda pula, sehingga membuat sulit terjadinya koordinasi.

Growth Triangles tidak berpengaruh atas persoalan-persoalan ini. Tidak seperti blok perdagangan, yang mengharuskan perubahan-perubahan nasional dalam institusional dan asministratif, growth triangles seringkali melibatkan hanya beberapa bagian dari negara-negara. Hal ini jelas mengurangi resiko politik dan ekonomi. Ketika sebuah triangle berhasil, keuntungannya dapat disebarkan ke bagian lain dari negara-negara anggotanya. Ini terjadi di Southern China, ketika pertumbuhan mulai terjadi di emapt Speial Economic Zones (SEZs) dan meluas secara perlahan ke Pearl River Delta wilayah dari Guangdong dan propinsi Fujian. Disisi lain, ketika ada konsekwensi yang harus dihadapai, dapat ditekan hanya pada wilayah yang terkait langsung. Hal ini tentunya menarik bagi negara-negara dalm transisi dari ekonomi terpusat menjadi ekonomi pasar.

Growth triangles dapat dibentuk dengan biaya yang lebih murah dan waktu yang lebih pendek dibandingkan dengan blok perdagangan formal, yang biasanya memakan waktu bertahun-tahun untuk diskusi dan persiapannya. Sebuah negara dapat membentuk beberapa growth triangles untuk menguji ragam pendekatan bagi kerjasama regional. Cina, Malaysia, dan Indonesia membentuk beberapa triangles dalam waktu bersamaan.

Ketika blok-blok perdagangan secara luas memfokuskan pada supplai pasar dari negara-negara anggota, growth triangles fokus pada struktur yang berorientasi ekspor dimana ukuran pasar regional tidak relatif terlalu penting untuk dipertimbangkan. Ini membuat growth triangles cocok bagi Asia, dimana pasar internaslnya lebih kecil dibandingkan Amerika Utara dan Eropa. Growth triangles juga mampu memberi keuntungan ekonomi bagi negara-negara non anggota, baik dengan cara menawarkan akses pasar maupun memberi ruang investasi asing.

Growth triangles berbeda dari export processing zones (EPZs). EPZs dibentuk dengan memberi ruang berbeda dari aturan-aturan nasional, dimana perusahaanperusahaan asing menikmati perlakuan khusus dalam segmen barang, pajak, dan akses terhadap infrastruktur. Sebagai imbalannya. Semua output dari EPZs harus diekspor. Bagi negara tuan rumah (host country), keuntungan utama adalah pendapatan dan penyerapan tenaga kerja, sementara bagi para investor yang menarik adalah biaya rendah untuk kategori ekspor.

Seperti halnya EPZs, growth triangles mengeksploitasi mobilitas internasional dari modal dan komparatif advantage dari tenaga kerja murah. 
Perbedaan yang signifikan adalah, keterlibatan lebih dari satu negara. Dengan mengeksploitasi skala ekonomi dan integrasi sumbe daya yang ada dari negaranegara anggota, growth triangles dapt menjadi lebih kompetitif. Selanjutnya, aktivitas-aktivitas growth triangles tidak terbatas pada manufaktur saja, bahkan bisa melibatkan sektor jasa, seperti pariwisata dan ekspor tenaga kerja. Disisi lain, koordinasi kebijakan memang diperlukan, khususnya untuk distribusi keuntungan, yang lebih kompeks dalam growth triangles dibandingkan dalam EPZs.

\section{Elemen Penting Kesuksesan Growth Triangles}

Apa yang membuat berhasil sebuah growth triangle di wilayah tertentu ? jawaban-jawaban atas pertanyaan ini penting tidak hanya untuk memahami eksistensi growth triangle yang sudah ada, namun juga untuk mendirikan yang baru.

Berdasarkan pengalaman di Selatan Cina dan Johor-Singapura-Riau triangle, faktor-faktor utama untuk suksesnya growth triangle adalah komplementaritas ekonomi, kedekatan geografis, komitmen poliitk, koordinasi kebijakan, dan pertumbuhan infrastruktur.

\section{Komplementaritas Ekonomi}

Komplementaritas ekonomi muncul dari perbedaan tingkat pertumbuhan ekonomi atau perbedaan sumber daya yang dimiliki oleh masing-masing pihak yang bergabung. Baik Southern China dan Johor-Singapura Riau triangles dikenal sebagai wilayah perkotaan yang berkembang dan kurang berkembang, pendapatan rendah. Pusat-pusat perkotaan di Asia Tenggara-Hong Kong, Singapura, Taipei -memiliki sektor indutri yang kuat, pasar keuangan yang baik, dan fasilitas-fasilitas infrastruktur yang mumpuni serta tenaga kerja yang terlatih. Mereka terbatas pada supplai tenaga kerja yang tidak terampil dan kelangkaan lahan, sehingga naiknya upah kerja dan harga dapat dipastikan akan mengurangi daya saing ekonomi mereka di pasar dunia. Sebaliknya, wilayah tetangga yang minim modal dan kemampuan manajerial dapat menyediakan tenaga kerja dan lahan yang dibutuhkan. Sehingga kemudian, redistribusi industri-industri yang berbasis tenaga kerja dari negara maju ke negara kurang berkembang jelas akan membawa keuntungan mutualisme.

Komplementaritas ekonomi dalam sebuah triangle juga dicirikan dengan adanya perbedaan-perbedaan pada tingkat teknologi dan kualitas serta pengalaman para personel yang terlibat di dalamnya. Fasilitas "soft technology" (Chen, 1993) dalam sektor jasa di Hongkong merupakan salah satu alasan utama berkembangnya Hong Kong menjadi pusat keuangan internasional dan menjadi sumber arus modal masuk ke wilayahnya.

Taipei, Cina, kaya akan teknologi "hard" dan soft" teknologi dalam sektor industri. Restrukturisasi dari sektor industrinya menuju teknologi yang intensif dan manufaktur dengan modal yang intensif pada pertengahan 1980-an. Hasilnya, industri-industri seperti tekstil, apparel, dan kulit menurun atau secara perlahan menghilang. Pada waktu yang bersamaan, ada kenaikan peluang bagi investasi keuangan lokal, justru setelah terjadinya surplus perdagangan yang sangat besar.

Singapura, baik sektor manufaktur maupun sektor jasa mampu menjadi sumber utama pergerakan ekonomi dan basis geografi, serta wilayah-wilayah 
tetangga juga mendapatkan manfaat dari jejaring manjerial, operasional dan logistik yang dimiliki Singapura.

Basis yang lebih luas untuk komplementaritas ekonomi dapat ditemukan dalam Trumen Delta Area, dimana integrasi ekonomi - teknologi Jepang dan Republik Korea , sumber daya alamnya Rusia dan Korea Utara, dan ketersediaan tenaga kerja dan sumber daya pertanian Cina.

Kontribusi-kontribusi komplementaritas dibutuhkan tidak hanya datang dari pihak-pihak yang secara fisik terlibat dalam Triangle. Di Shenzhen, setengah dari FDI datang dari Hong Kong dan Taipei, Cina pada tahun 1990. Situasi yang sama juga dapat ditemukan di Batam. Komplementaritas ekonomi antar pihak-pihak dalam Trumen Delta terkesan lemah, dan modal justru diharapkan datang lebih besar dari Jepang dan Republik Korea. Selanjutnya, dikarenakan sebuah growth triangle berorientasi pada struktur sektor ekspor, outputnya bergantung lebih besar pada pasar eksternal dibandingkan pasar internal, yang kemudian dapat mengurango komplementaritas ekonomi dalam triangle itu sendiri, setidaknya untuk dimensi demand.

\section{Kedekatan Georgrafis.}

Studi-studi empiris menunjukkan bahwa tren perdagangan dengan negaranegara tetangga terjadi jika biaya-biaya transportasi dan komunikasi dapat diminimalisir (Summers, 1991). Sehingga, tidak mengejutkan jika kedekatan geografis adalah salah satu faktor penentu bagi modal yang masuk datang Hong Kong ke Guangdong, untuk investasi dari Taipei, Cina masuk ke Xiamen, atau perusahaan-perusahaan Singapura untuk relokasi di Johor dan Batam. Kesamaan dalam bahasa dan latar belakang budaya, juga sering menjadi unsur untuk lebih baik dalam memahami dan menjalin hubungan bisnis yang lebih dekat.

\section{Komitmen Politik dan Koordinasi Kebijakan}

Komitmen Politik dari pemerintah melibatkan koordinasi politik diantara pihak-pihak yang terlibat menjadi faktor-faktor kunci bagi suksesnya sebuah triangle. Pada level nasional, dibutuhkan implementasi kebijakan yang tepat terkait dengan tarriff, regulasi tenaga kerja, real estate, keuangan, investasi asing, dan foreign exchange. Semua kebijakan terkait harus didukung penuh dan diimplementasikan baik oleh pemerintah pusat maupun pemerintah lokal/daerah. Contohnya, komitemen pemerintah pusat dikritik terkait regulasi perpajakan Indonesia terhadap investasi asing langsung di Batam, yang mengizinkan 100 persen kepemilikan saham asing, pendirian sektor privat dari industrial estates (Chia dan Lee, 1992).

Dalam Trumen Delta Triangle, komitmen politik diukur dari negara-negara yang terlibat sedari awal program pertumbuhan disepakati. Trumen Delta juga menunjukkan adanya dukungan politik yang besar, multilateral development organizations- dalam kasus ini United Nations Development Programme -dapat memainkan peran penting untuk menyediakan dana bagi study project dan design demi mempertahankan peran non-partisipan. 
Jika dibandingkan dengan Johor-Singapura-Riau dan Trumen Delta Triangles, koordinasi kebijakan formal antar anggota dari Southern China Triangle relatif lemah, dengan pertumbuhan triangle yang banyak berfokus pada tekanantekanan pasar dan sektor privat. Namun bagaimanapun, kebijakan-kebijakan pemerintah masih krusial dalam menentukan apakah dan untuk apa jaringan ekonomi perlu diperluas. Reformasi ekonomi Cina dan kebijakan "open door" pada tahun 1978, pemerintah Cina meninggalkkan kebijakan lamanya dan menyederhanakan regulasi/prosedur bagi proyek-proyek investasi asing. Pemerintah Hong Kong juga memainkan peran penting dalam meningkatkan sektor privat untuk merelokasi basis produksinya ke Southern Cina. Di Taipei, Cina, pemerintah mengontrol impor produk dari wilayah utama, seperti halnya indirect export dan investasi, yang secara perlahan sudah dilebaralisasi sejak tahun 1985.

\section{Pertumbuhan Infrastruktur}

Pertumbuhan infrastruktur adalah faktor yang paling penting dalam menciptakan lingkungan ekonomi yang kondusif bagi pertumbuhan sebuah growth triangle. Di Southern China triangle, contohnya, persiapan dari empat SEZs melibatkan perkembangan wilayah dan konstruksi modal dalam skala besar. Dalam tahapan pertama pertumbuhan, konstruksi infrastruktur berada dibawah konsep "Five Opens" dan "One Leveling". Supplai air, power supplai, jalanan, navigasi dibuka untuk lalu lintas, telekomunikasi dibuka untuk bisnis, dan lahan-lahan diizinkan untuk gedung. Program pembangunan infrastruktur dalam skala yang lebih besar diluncurkan pada tahun 1986, fokus pada expressway dan railway links (jalur kereta api) antara SEZs dan propinsi Guangdong dan Fujian, demikian juga dengan jalur udara menuju belahan dunia yang lain. Investasi masiv juga diarahkan untuk pertumbuhan electric power dan proyek-proyek telekomunikasi.

Kecenderungan yang sama juga dapat dilihat di Johor-Singapura-Riau Growth Triangle. Ketika infrastruktur relatif berkembang di wilayah Johor, proyekproyek infrastruktur yang besar masih diperlukan di Batam Industrial Park dan Bintan dalam Integrated Development Project.

\section{Mengevaluasi Keuntungan dan Kerugian dari Growth Triangles}

Hampir semua studi yang memaparkan growth triangles, tidak mengkaji secara detail keuntungan-keuntungan potensial yang dimiliki growth triangles. Data untuk mengukur biaya dan keuntungan secara akurat tidak tersedia bagi hampir semua triangles. Analsia-analisa cost-benefit cenderung berbeda dari satu negara dengan negara lain, dan effek yang ditimbulkan juga berbeda, sehingga cenderung sulit untuk mengukurnya. Tanpa adanya penghitungan secara aktual cost dan benefit, maka sumber daya yang ada tidak akan dapat dioptimalkan. Lebih tegasnya lagi, sebuah pemahaman yang baik dari keseimbangan dan distribusi cost dan benefit adalah unsur kritis bagi hubungan yang berkelanjutan diantara anggota triangles. Terakhir, pengetahuan akan cost and benefit diperlukan tidak hanya bagi perluasan triangles secara efesien dan penciptaan triangles yang baru, namun juga bagi perhitungan realistis dari kemungkinan-kemungkinan dan pembatasan-pembatasan growth triangles secara umum. 


\section{Keuntungan}

Inti dari setiap triangle adalah ide bahwa keragaman sumber daya yang dimiliki antar wilayah yang saling terkait mampu meningkatkan kompetisi indvidual para anggota dalam promosi ekspor. Dalam teori, growth triangles mengeksploitasi mobilitas modal internasional sekaligus menggabungkannya dengan keberadaan sumberdaya tenaga kerja untuk menghasilkan produk-produk dagang yang kemudian akan diekspor ke mana saja. Meskipun seluruh keuntungan dan kerugian dari sebuah growth triangle terpapar melalui sudut pandang ini, tujuan dari masing-masing negara anggota cenderung berbeda. Negara-negara yang berlimpah kaya akan modal, secara umum akan berharap untuk mendapatkan angka yang juga tinggi atas modal yang sudah mereka keluarkan, sementara negara yang berlimpah tenaga kerja berharap adanya impor modal sebagai balasan dari adanya ekspor-ekspor manufaktur. Bagi negara yang mengeskpro modal, kehadiran tenaga kerja murah di wilayah terdekat mereka akan memberi ruang untuk restrukturasi ekonomi, dan relokasi "industri-industri sunset" dan rasionalisasi penggunaan sumber daya untuk produksi dan distribusi melalui integrasi vertikal.

Perbedaan biaya tenaga kerja dalam sebuah triangle dapat menjadi sesuatu yang substansial. Misalnya, pada tahun 1989, upah tenaga kerja bulanan untuk tenaga kerja Hong Kong di sektor manufaktur mencapai HK\$5,520,sementara untuk jenis pekerjaan yang sama di Guangzhou dan Shenzen SEZ hanya HK\$800. Hal yang sama untuk upah bulanan di tahun yang sama di Singapura adalah $\$ 350$ untuk upah pekerja yang tidak terampil, \$150 di Johor, dan \$90 di Batam (Chen dan Ho, 1993; Kumar 1993). Restrurisasi ekonomi dalam merespon perbedaan-perbedaan tersebut memberi ruang bagi para eksportir modal untuk memindahkan aktivitasaktivitas yang menelan biaya tinggi ke wilayah lain. Keuntungan lain bagi para eksportir modal adalah akses untuk ragam aktivitas hiburan, dan jaminan adanya bahan mentah yang diperlukan untuk produksi, dan penciptaan pasar-pasar baru untuk beragam produk dan jasa.

Bagi negara-negara pengimpor modal, keuntungan statis sama halnya dengan EPZs yakni: investasi asing, foreign exchange earnings, penyerapan tenaga kerja, transfer teknologi, pendapatan pajak, dan lain-lain. Investasi asing dan penerimaan dalam foreign exchange untuk item-item ekspor memang menguntungkan. Ekspor secara umum meningkat baik di Southern China maupun di Johor-Singapura-Riau Triangles. Ekspor Cina ke Hong Kong naik dari \$5.7 billion pada tahun 1981 mencapai lebih dari $\$ 26.7$ billion pada tahun 1991. Untuk periode yang sama, ekspor Hong Kong ke Cina naik dari \$1.9 billion mencapai \$17.5 billion (Chen dan Ho, 1993). Hal yang sama juga terjadi dimana, total ekspor dari Batam naik dari hanya \$20.9 million pada tahun 1986 mencapai \$210 million pada tahun 1991. Perlu dicatat, bahawa foreign exchange earningnya dari ekspor mungkin lebih sedikiti dibandingkan gross earningnya karena adanya biaya yang dikenakan untuk input yang diimpor.

Penyerapan tenaga kerja merupakan keuntungan substansial lain, sebagaimana yang ditunjukkan oleh Batam. Pada tahun 1985, populasi secara keseluruhan hanya 58.000. angka ini naik menjadi 107.600 pada tahun 1991. Sejumlah pekerja di kepualauan naik dari 6000 mencapai lebih dari 23.000 pada 
periode yang sama (Kumar, 1993). Namun bagaimanapun, seperti halnya export earningnya, tidak semua jenis pekerjaan dapat memberi keuntungan yang tetap. beberapa jenis pekerjaan bisa saja tidak cocok di triangle. Dalam kasus tertentu, harus diimpor dari wilayah lain. Biaya-biaya transaksi seperti ini harus dimasukkan dalam kalkulasi untung rugi sebuah growth triangle. Dalam kasus yang lain, situasi yang mungkin bisa dicegah adalah mencegah tenaga kerja migran pindah ke growth triangle sebagai upaya merespon perbedaan upah kerja. Upaya untuk menghambat hal ini terjadi tentu saja membutuhkan biaya dan juga distorsi pasar tenaga kerja yang menjadi penyebab terjadinya penggunaan tenaga kerja yang tidak efesien. Perpindahan tenaga kerja menjadi isu yang tidak bisa diabaikan baik di Southern China maupun di JSR Triangle (SIJORI).

Hal lain yang menjadi perhatian, peluang-peluang pekerjaan formal harus menuju pada sebuah perbaikan dalam pendapatan ril tenaga kerja dalam growth triangle. Namun, keuntungan dari pendapatan yang lebih tinggi harus diimbangi dengan biaya yang dikeluarkan untuk mengatasi perubahan sosial yang timbul di wilayah asal dan tujuan tenaga kerja. Pendapatan lebih tinggi bisa saja bersifat temporer, terutama bagi para tenaga kerja dimana skill mereka yang dibutuhkan di triangle, tidak lagi diperlukan atau tidak mengasilkan uang ketika kembali ke tempat asal mereka .

Keuntungan-keuntungan yang dipaparkan diatas, dapat dipandang sebagai keuntungan jangka pendek. Sebaliknya, ada keuntungan jangka panjang yang diharapkan, seperti transfer teknologi dan peningkatan keterampilan. Kepemilikan perusahaan asing, penggunaan teknologi asing, dan ketidakhadiran dari penelitian lokal serta kemampuan-kemampuan berkembang sepertinya membatasi terjadinya transfer teknologi, meskipun dalam jangka waktu yang lebih panjang. Keuntungan lebih yang mungkin bisa didapatkan adalah peningkatan jumlah tenaga kerja. Dalam pelatihan tenaga kerja, memungkinkan para pekerja untuk mempelajari nilai-nilai dan praktek-praktek penting yang bermanfaat, seperti misalnya disiplin, teknikteknik manajerial, dan kontrol kualitas. Skill-skill seperti ini dapat dipelajari dan ditransfer.

Keuntungan jangka panjang lain terkait dengan ekonomi nasional. Kenaikan pendapatan dan penyerapan tenaga kerja yang mempromosikan industri-indutri jasa dalam triangle dan adanya peluang-peluang pekerjaan di luar. Jika ini berhasil, sebuah growth triangle dapat menjadi sebuah agen penting untuk pertumbuhan sektor-sektor lain, dengan memberi fasilitas kepada para investor potensial dan menjadikan pemerintah untuk mampu mengadaptasi kebijakan yang menarik investor.

Sebuah growth triangle juga dapat memfasilitas secara fisik wilayah tertentu terkait kebijakan lingkunan yang kondusif untuk promosi ekspor. Keputusankeputusan kebijakan yang terbatas pada wilayah yang kecil, seandainya kebijakankebijakan tersebut efektif dalam sebuah triangle, maka kebijakan tersebut dapat diperluas untuk keuntungan ekonomi secara keseluruhan. Oleh karena itu growth triangle sesuai bagi engara-negara yang mengalamai kesulitan akan adanya batasanbatasan ekonomi, politik maupun lingkungan. Konsep growth triangle menarik bagi negara-negara yang sedang melakukan proses reformasi ekonomi, baik sebagai 
instrumen transisional maupun sebagai jalan mendukung reformasi yang sedang berlangsung. Sejauh ini, triangle mampu mempromosikan peluang-peluang ekonomi, dan memiliki dampak positif yang cukup besar bagi negara-negara yang berpartisipasi didalamnya.

\section{Kerugian}

Ketika membicarakan kerugian dari sebuah growth triangle, seseorang harus melihat biaya secara keseluruhan dan cara dimana biaya-biaya tersebut dibagi oleh para partisipan. Meskipun sulit untuk membagi secara tepat dan adil biaya-biaya tersebut, namun beberapa pembagian biaya langsung dan tidak langsung tetap diperlukan. Biaya langsung (direct costs) termasuk berhubungan dengan pertumbuhan dan mempertahankan triangle. Biaya inti pertumbuhan berkaitan dengan persiapan, instalasi jalan-jalan, persiapan suppai power dan air, termasuk konstruksi dari fasilitas-fasilitas tempat tinggal bagi para tenaga kerja dan semua pihak yang terlibat. Total biaya untuk semua operasional ini menjadi substansial. Fasilitas-fasilitas pelabuhan harus ada dalam sebuah wilayah triangle, sehingga biaya untuk pembangunan yang lain dapat ditekan ataupun dikurangi.

Biaya perawatan penting jika sebuah growth triangle ingin meembagi keuntungan yang didapat dengan wilayah lain disekitarnya. Biaya maintenance akan cenderung tinggi jika administrasi publik dan kemampuan manajemen minim. Kekurangan-kekurangan tersebut akan berdampak terhadap prilaku, yang kelanjutannya akan berdampak terhadap daya tarik triangle bagi para investor. Untuk mengatasi hal ini, sebuah badan independen yang mengawasi infrastruktur diperlukan. Akses bagi lembaga independen ini harus mungkin harus dikhususkan jika kemampuan perencanaan dan administratif, termasuk mobilisasi sumber daya dan perencanaan keuangan masih lemah. Ini adalah masalah utama di wilayahwilayah yang jauh dari pusat politik sebuah negara.

Indirect cost (biaya tidak langsung) termasuk didalamnya subsidi dan biayabiaya lain yang diperuntukkan untuk menarik para developer dan investor. Kategori biaya ini termasuk subdisi atas biaya lahan, bangunan, dan perangkat-perangkat lain, sebagaimana layaknya subsidi yang diberikan untuk komoditi-komoditi domestik. Perubahan kebijakan yang signifikan juga dibutuhkan untuk menarik arus investasi, atau setidaknya untuk mengharmonisasikan kebijakan-kebijakan dengan anggota triangle yang lain, hal ini juga dapat dimasukkan dalam kategori biaya-biaya tambahan. Jaminan-jaminan operasional investasi, prosedur-prosedur arbitrase, dan insentif-insentif yang ditawarkan akan menarik industri-industri untuk datang, juga masuk dalam kategori biaya yang harus dikeluarkan oleh negara-negara anggota maupun kelompok-kelompok kepentingan dalam negara-negara tersebut.

Biaya-biaya dari sebuah growth triangle juga termasuk biaya negatif eksternal atau hal-hal yang tidak diinginkan yang berasal dari lingkungan eksternal. Termasuk didalamnya arus populasi dan tenaga kerja potensial serta biaya degradasi lingkungan. Pemindahan investasi dan modal dari negara luar ke salah satu negara anggota juga akan menimbulkan biaya. Termasuk didalamnya yang berkaitan dengan upaya-upaya institusional untuk mengatasi persoalan-persoalan domestik maupun eksternal demi pertumbuhan growth triangles, khususnya alokasi 
keuntungan di regional tersebut. Persoalan-persoalan potensiak termasuk diantaranta perbedaan pendapatan regional, masalah-masalah sosial dan etnis, dan kesulitankesulitan transaksi diantara level pusat dan pemerintah yang dibawahnya terutama jika terdapat otonomi (Asia Development Outlook, 1992).

Tidak semua populasi dalam sebuah growth triangel akan mendapatkan akses terhadap peluang ekonomi baru yag ada. Perbedaan pendapatan dalam triangle dan kelompok-kelompok eksternal justru akan meningkat dikarenakan adanya perbedaan akses terhadap peluang investasi dan pekerjaan termasuk juga barangbarang publik.

Hubungan antranegara dalam sebuah triangle juga merupakan dimensi lain dari biaya yang harus dipikirkan. Harmonisasi kebijakan untuk meminimalisir perbedaan-perbedaan yang ada dalam standar-standar industi, klasifikasi kebiasaan, regulasi tenaga kerja, dan hambatan-hamabatan tarif dan non-tarif juga menjadi elemen penting untuk dipertimbangkan. Biaya-biaya yang berhubungan dengan harmonisasi muncul pada tataran pemerintah dan selama operasional triangle. Oleh karena itu penting untuk mencari cara meminimalisir biaya yang muncul. Harmonisasi menjadi sesuatu yang penting dalam struktur industrial sebagai respon terhadap realitas-realitas eksternal yang ada. Bagi negara-negara maju,situasi ini menjadi sebuah "pemajuan kapasitas indutrial", sementara bagi mereka yang belum berkembang, ini menjadi bagian untuk memperbaiki kemampuan teknologi dan akuisis.

Distribusi biaya dan keuntungan menyajikan tantangan bagi para paritisipan dalam sebuah growth triangle. Kebijakan-kebijakan yang eksplisit untuk menjamin keuntungan sebuah growth triangle akan menyebar ke wilayah lain dari negaranegara anggota harus menjadi perhatian bagi negara partisipan. Manufaktur yang berkonstrasi pada pasar yang lebih besar hanya akan efektif jika kebijakan-kebijakan yang dibuat menjamin biaya transportasi rendah dan ekonomi skala besar akan menarik bagi perusahaan-perusahaan manufaktur (Krugman, 1991).

\section{Melihat Masa Depan Growth Triangles}

Tingginya angka pertumbuhan di Southern Cina dan rendahnya biaya dalam pembentukan Johor-Singapura-Riau triangle yang dapat dikatakan berkembang dengan baik, growth triangle menjadi sesuatu yang dipertimbangkan oleh region lain di Asia. Dua pendahulunya yang berhasil adalah North ASEAN Growth Triangles di Asia Tenggara dan Trumen River Area Development Program di Northeast Asia. Yang terakhir bahkan mendapatkan bantuan dana dari United Nations Development programme for feasibility studies. Apakah growth triangles akan menjadi pilar Asia atau terminologi lain dalam pertumbuhan ekonomi bergantung pada sejumlah faktor.

Masa depan growth triangles akan ditentukan oleh keberlanjutan arus investasi asing yang masuk ke wilayah tersebut dan keinginan negara-negara tetangga untuk bekerjasam secara ekonomi. Meskipun dua kondisi ini terlihat bukan sesuatu yang sulit, terbatasnya progress dari bentuk lain kerjasama ekonomi regional, dan beberapa persoalan yang dihadapi growth triangles, maka diperlukan metode-metode yang memang aplikatif. 
Kerjasama regional membutuhkan itikad politik yang kuat dan komitmen yang tinggi dari sektor publik, untuk mengurangi resiko dan ketidakpastian (Pangestu et al, 1992). Mempertahankan keberlangsungan arus investasi asing mensyaratkan adanya sistem perdagangan global yang terbuka. Kebijakan yang membatasi negara-negara yang terlibat dapat berpengaruh terhadap keefektifan dari strategi pertumbuhan ekspor yang menjadi konsep dasar dari growth triangle (Gray, 1991). Namun bagaimanapun, tidak dapat dipungkiri bahwa, tren-tren domestik, regional dan global yang ada menunjukkan bahwa growth triangles memiliki masa depan yang baik.

Ada tekanan-tekanan domestik untuk memperluas growth triangles di negara-negara yang berorientasi keluar outward-oriented, export-led-growth strategies- terutama bagi negara-negara yang mengalami persoalan terkait ekspor. Negara-negara yang bergabung akan mendapatkan keuntungan dari adopsi kebijakan-kebijakan promosi ekspor, namun berhadapan dengan populasi yang menginginkan angka pertumbuhan yang tinggi dan naiknya standanr hidup. Pada waktu yang bersamaan, investasi asing, dibutuhkan untuk pertumbuhan ekspor yang tinggi, yang berhadapan dengan naiknya upah karena tenaga kerja yang terampil dan infrastruktur. Growth triangles memberikan jalan bahi negara-negara yang kurang menarik dalam hal investasi untuk mempertahankan beberapa kompetisi yang mereka miliki sembari memperluas basis ekspor mereka dan meningkatkan efesiensi industrial mereka.

Bagi negara-negara yang memang mengacu pada eksport orientasi, growth triangles memberikan jalan yang baik untuk menerapkan strategi-strategi tersebut untuk mengakselerasikan pertumbuhan ekonomi. Meingkatnya investasi asing, tenaga kerja, dan ekspor juga dibutuhkan untuk menekan kemungkinankemungkinan kerugian dalam memasuki sebuah sistem ekonomi yang baru. Bagi negara-negara ini, growth triangles akan menjadi cara yang menarik untuk masuk ke pasar dunia selama periode reformasi dan restrukturasi ekonomi yang tidak bisa dibilang mudah.

Investasi asing intra-Asia memiliki kondisi sekaligus keinginan dari pertumbuhan growth triangles. Jepang harus merestrukturisasi ekonominya untuk meningkatkan kualitas kehidupan warganya dan mengurangi ketidakseimbangan eksternal. Negara-negara industrialisasi baru Asia juga harus melakukan restrukturisasi dalam merespon perubahan-perubahan global yang ada. Investasi intra-Asia akan meningkat sebagai respon dari restrukturisasi ini, dan growth triangles akan menjadi sebuah metode logis yang menguntungkan.

Kemunculan aliansi ekonomi regional dan blok-blok perdagangan juga dapat mempromosikan pertumbuhan dari growth triangles yang ada. Kesulitan-kesulitan yang dihadapi pada putaran Uruguay GATT, bersamaan dengan menguatnta European Community dan kemunculan North America Free Trade Agreement (NAFTA) juga memperkuat negara-negara Asia untuk memikirkan kembali cost dan benefit dari kerjasama regionak. Mereka dapat melihat growth triangles sebagai cara untuk meningkat daya kompetisi mereka dan melindungi diri mereka dari perubahan-perubahan dalam sistem ekonomi eksternal, tanpa harus mengorbankan kedaulatan ekonomi. Growth triangels dapt juga dipandang sebagai sebuah cara 
membangun keseimbangan dalam negosiasi-negosiasi dengan blok-blok perdagangan eksternal.

\section{SIMPULAN}

Minimnya data dan novelty dari topik ini, menjadikan observasi harus dilakukan. Pertama karena, bahwa growth triangle adalah sebuah bentuk yang tepat untuk pelaksanaan kerjasama regional bagi negara-negara Asia. Growth triangles lebih berorientasi ekspor dibandingkan blok-blok perdagangan, dan tidak terlalu terprovokasi dari kepentingan-kepentingan luar. Growth triangles juga relatif rendah biaya karena pembentukannya yang relatif pendek. Growth triangles juga dapat dikembangkan sesuai dengan kondisi yang ada.

Meskipun growth triangles tumbuh secara potensial, beberapa kondisi diperlukan untuk mengukur kesuksesan mereka. Syarat utama untuk sebuah growth triangles adalah adanya komplementaritas ekonomi diantara negara-negara yang terlibat. Perbedaan sumber daya ini dapt menjadi magnet utama yang menggerakkan kerjasama antar negara yang berbeda dapat saling menguntungkan. Kedekatan geografi juga diperlukan untuk mengurangi biaya-biaya transaksi dan transportasi, serta mendapatkan keuntungan dari keterikatan budaya dan bahasa. Para anggota harus secara politik berkomitmen dan bersedia untuk memberi ruang untuk kemudahan akses, infrastruktur fisik, khususnya pelabuhan-pelabuhan demi menekan biaya. Terakhir, keuntungan harus didistribusikan sevara merata diantara negara anggota triangle yang berpartisipasi.

Bab ini mengkaji cost dan benefit yang berhubungan dengan growth triangles. Memungkinkan untuk disimpulkan bahwa para anggota meminimalisir biaya sejak dari awal pembentukan. Jika memungkinkan dengan mengambil keuntungan dari fasilitas yang sudah ada. Dalam terminologi benefit, pertimbanganpertimbangan jangka panjang seperti pertumbuhan regional dan manusia jauh lebih penting dibandingkan dengan pertimbangan-pertimbagan tradisional seperti foreign exchange earnings dan generasi tenaga kerja. Growth triangles juga dapat bermanfaat dalam menunjukkan pentingnya reformasi ekonomi secara keseluruhan demi mengurangi distorsi-distorsi yang ada.

Meskipun keuntungan growth triangles potensial, unsur biaya (cost) tetap ada. Cost utama terkait dengan pertumbuhan modal dan merawat fisik infrastruktur. Biaya signifikan kain termasuk adanya gerakan populasi yang besar. Kondisi pergerakan populasi ini muncul dari adanya degradasi lingkungan dan peningkatan perbedaan penghasilan.

Secara keseluruhan, masa depan growth triangle dapat diukur. Bagi banyak negara, growth triangles berarti meningkatkan ekspor dan menekan biaya tenaga kerja. Keinginan untuk memasukan zona kerjasama regional juga difasilitasi oleh restrukturasi ekonomi Asia yang cenderung mengarah pada tingginya arus investasi. Pada akhirnya, dengan blok-blok perdagangan dan tren proteksionis yang muncul di belahan dunia yang lain, growth triangles dapat dipahami sebagai jalan bagi negaranegara Asia untuk melindungi diri mereka dalam melawan realitas global yang ada melalui promosi kompetisi biaya dalam ekspor. 


\section{DAFTAR PUSTAKA}

Asia Development Outlook, 1992. http://hdl.handle.net/11540/2258

Chen, J-Y., J-F Lu. (1993). A new metric for object-oriented design, Information and Software Technology, Volume 35, Issue 4, Pages 232-240. https://doi.org/10.1016/0950-5849(93)90071-A.

Chia, S.Y. dan Lee, T. Y. (1993). Subregional ecconomic zones: A new motive force in Asia Pacific development. Inc. F. Bergsten dan M. Nolands (eds) Pacific Dynamism and International Economic System (pp. 225-69). Washington: Institute for International Economics.

Gray, P.A. (1991), Economic Development and African Americans in the Mississippi Delta*. Rural Sociology, 56: 238-246. https://doi.org/10.1111 /j.1549-0831.1991.tb00434.x

Heng, Toh Mun (2006). Development in the Indonesia-Malaysia-Singapore Growth Triangle. SCAPE Working Paper Series. Paper No. 2006/06- 31 March 2006.

Heng, Ton Mun \& Jiang Bo. (2016). The SIJORI Cross Border Region as an Economic Entity in 1990 and 2012, and Perspective for 2030 dalam Hutchinson, Francis E \& Terence Chong, The SIJORI Cross Border Region Transnational Politics, Economics, and Culture. Singapura: ISEAS Publishing.

Kakazu, Hiroshi. (1999). Growth Triangles in Asia A New Approach to Regional Cooperation. Working Paper no. 9. Politics and International Relations Series 1999-03 (Former No. Asia Pacific series 1999-3 April.

Krugman, P. (1991). History and Industry Location: The Case of the Manufacturing Belt. The American Economic Review, 81(2), 80-83. Retrieved March 4, 2021, from http://www.jstor.org/stable/2006830

Kumar, S.; Lee Tsao, Y. (1990). A Singapore Perspective. Dalam Lee Tsao, Y (ed), Growth Triangle: The Johor-Singapore-Riau Experience. Institute of Southeast Asia Studies and Institute of Policy Studies, Singapore.

Kumar, Pradeep. (1993). From Uniformity to Divergence: Industrial Relations In Canada and the United States. Kingston, Ontario: IRC Press, Queen's University 
Kumar, S., and Siddique, S. (1994). Beyond economic reality: new thoughts on the growth triangle. Southeast Asian Affairs, 47-56

Lee Tsao Yuan. (1991). ed. Growth Triangle: The Johor-Singapore-Riau Experience. Singapore, Institute of Southeast Asian Studies.

Macleod, S., \& Tg, M. (1996). The Singapore-Johore-Riau growth triangle: an emerging extended metropolitan region.

McGee, T.G. dan Robinson, I. (1995). The Mega-Urban regions of Southeast Asia, Vancouver. Canada: University of British Columbia.

McGee, T.G., and Greenberg, C. (1994). The Emergence of Extended Metropolitan Regions in ASEAN:Towards the Year 2000. ABEAN Economic Bulletin, Vol.9, No.1.

Myo Thant, Min Thang dan Kakazu, H. (eds) Growth Triangles in Asia: A New Approach in Regional Economic Cooperation. Manila: ADB.

Pangestu, M., Soesastro, H., \& Ahmad, M. (1992). A New Look at Intra-ASEAN Economic Co-operation. ASEAN Economic Bulletin, 8(3), 333-352. Retrieved March 4, 2021, from http://www.jstor.org/stable/25770388

Scalapino, R. (1992). The United States and Asia: Future Prospects, Foreign Affairs. Winter, pp.19-40.

Schott, J.J. (1991), Trading Blocs and the World Trading System. World Economy, 14: 1-18. https://doi.org/10.1111/j.1467-9701.1991.tb00748.x

Summers, R. and A. Heston, 1991, "The Penn World Table (Mark 5): An Expanded Set of International Comparisons, 1950-1988," Quarterly Journal of Economics, 106: 327-368.

Tsao Yuan, L. (1995). The Johor-Singapore-Riau growth triangle: effect economic integration. 30 Nov-3 Des 1992. Bangkok Thailand, pp. 269-82. 